International Journal of Advanced Biological and Biomedical Research Available online at http:www.ijabbr.com

Volume 7, Issue 4 (2019) pp. 298-305

DOI: 10.33945/SAMI/IJABBR.2019.4.2

Original Article

\title{
Evaluation of Neem Dust Formulations for the Control of Sorghum Stemborers in the Semi-Arid Zone of Nigeria
}

\author{
Emmanuel Okrikata1, ${ }^{1}$, Chinwe Edith Anaso \\ ${ }^{1}$ Department of Biological Sciences, Federal University Wukari, Nigeria \\ ${ }^{2}$ Department of Biological Sciences, University of Maiduguri, Nigeria \\ *Corresponding Author E-mail: eokrikata@gmail.com
}

Received: 13 March 2019, Revised: 25 May 2019, Accepted: 27 May 2019

\begin{abstract}
Sorghum stemborer species remains key yield limiting factor for sorghum production in the Nigerian semi-arid region. When they can afford, farmers rely almost solely on synthetic insecticides for control. Owing to the misuse and environmental and health challenges attributed to the use of synthetic insecticides, a two-year field study was carried out at the University of Maiduguri Research Farm to evaluate the efficacy of various neem dust formulations for the control of Sorghum stemborers. The experimental design was Randomized Complete Block Design and various neem dust formulations were compared with carbaryl dust and the control (untreated). All the insecticidal treatments significantly $(\mathrm{p}<0.05)$ reduced stalk and peduncle damage caused by stemborers with a resultant increase in grain yield when compared with the control. Neem Kernel Powder (NKP)+Finesand proved more superior in efficacy than all the other insecticidal treatments in checking stemborer damage.
\end{abstract}

Key words: Carbaryl dust, Formulation, Integrated pest management, Neem based treatments, Neem kernel powder.

\section{Introduction}

Sorghum (Sorghum bicolor [L.] Moench) is the most important food crop in the savanna areas of West Africa. It's stalk is used for mulching, animal feed, roof, shade, kiosks, bedding and fence building (Adegbola et al., 2013; MAFAP, 2013). The most important and most widespread field insect pest of sorghum are the lepidopterous stemborers (Malgwi and Adamu, 2013). They constrain production of Sorghum wherever it is grown (Mathieu et al., 2006). Report on grain losses in sorghum due to stemborer reveals that crop loss could range from 10-100\% (Kfir et al., 2002; Ajala et al., 2010; Malgwi and Adamu, 2013; Okweche et al., 2013).

While the characteristic external symptoms of stemborer infestation include leaf injury and presence of holes on stems [Stalks and peduncles] (Mathieu et al., 2006; Van den Berg, 2009), important internal symptoms of infestation is the extensive tunneling due to their feeding activities. Farmers largely rely on synthetic insecticides which are in most cases expensive especially for the resource poor farmers. Aside economic factors, 
chemical control has been reported to have some health and environmental drawbacks in addition to pesticide resistance and pest resurgence (Oswald, 2005). Owing to the nocturnal habits of the adult stemborer species and cryptic lifestyle of the larvae, control is generally challenging. Whorl application of Carbaryl 85WP, granular Endosulfan 5G and granular Trichlorphon 5G have been recommended for their management (Malgwi and Adamu, 2013). However, due to their persistence and high health and environmental risks, some of these synthetic insecticides are now banned.

Of the several plant species screened as sources of biopesticides, neem (Azadirachta indica A. Juss) is perhaps the most promising because it possesses nearly all the characteristics of an ideal biopesticidal agent as listed by (Ahmed and Grainge 1986). Since good results against lepidopterous stemborers have been obtained by applying neem products into the whorls of cereals (Seshu Reddy, 1988; Wahedi et al., 2016), an attempt was made in these trials to protect sorghum from stemborers using various neem dust formulations.

\section{Materials and methods}

A two-year field experiment was conducted at the University of Maiduguri Teaching and Research Farm. Seeds of sorghum (var. $\mathrm{KSV}_{4}$ ) used for the trials were obtained from Borno State Agricultural Development Programme (BOSADP).

\section{Land preparation and management}

The land was ploughed and harrowed after which a $121 \times 21 \mathrm{~m}$ area was demarcated into four blocks (replicates). The blocks were separated by $1 \mathrm{~m}$ alleys which served as a passage between the blocks. Each block had 6 plots each measuring, $10 \times 10 \mathrm{~m}\left(100 \mathrm{~m}^{2}\right)$ and the plots were separated by $30 \mathrm{~cm}$ bounds.

Following land preparation, $200 \mathrm{kgha}^{-1}$ of compound fertilizer, NKP (15:15:15) was applied by broadcasting at the time of sowing and $75 \mathrm{kgha}^{-1}$ of Urea was applied by side placement at 6 weeks after sowing. The crop was left to natural infestation of pest. Meanwhile, in order to ensure good stemborers (pest) population build-up, the crop was sown a few weeks after rain establishment. Seedlings were thinned to 2 plants per stand after 2 weeks of emergence. Seeds were sown at $75 \times 40 \mathrm{~cm}$ inter- and intra-row spacing, respectively.

\section{Experimental design and treatments}

The experimental design used was the Randomised Complete Block Design (RCBD). The treatments evaluated were;

Equal parts by weight (50/50, w/w) of:

Neem Kernel Powder (NKP) + Fine sand,

$\mathrm{NKP}+$ Kaolin dust,

$\mathrm{NKP}+$ Sawdust,

Carbaryl dust (a recommended synthetic insecticides for stemborers) and,

Control (untreated). 


\section{Preparation of treatments}

Ripe fruits from neem trees (A. indica) in Maiduguri, Borno State of Nigeria were collected, washed and air-dried under shade. The fruits were cracked to obtain the kernel which were further air dried. The NKP was prepared by pulverizing the neem kernel with the aid of a Molinex brand electric blender (MX-795N). The powder obtained was further passed through a Suplex Standard Test Sieve $(500 \mu \mathrm{m})$ to improve the smoothness of the particles. Kaolin dust was equally prepared by grinding pellets of kaolin in an electric grinder and further sieving the material through the sieve to make it fine. Finesand (from riverbank) was prepared by sieving sand particles through the sieve while sawdust (derived from Iroko wood) was obtained from Maiduguri wood market. The various mixtures (treatments) were formulated by thoroughly mixing equal parts by weight of NKP and the respective diluents in a wide container. The individual mixture was further homogenized in the electric blender.

\section{Application of treatments}

At 20 days after sowing (DAS), the treatments were applied (between 6:30 am and 7:30 am) by introducing approximately $5 \mathrm{~g}$ of each pesticide formulation into the whorl of sorghum plants. This was repeated at 10 days intervals until 50\% booting was achieved.

\section{Data collection and analysis}

The data were collected from the 4 middle rows which covers a net plot size of $10 \times 5.25$ $\mathrm{m}\left(52.5 \mathrm{~m}^{2} / \mathrm{plot}\right)$. The data collected were proportion of stalks and peduncle tunneled their tunneling length and grain yield (kg/plot). The collected were subjected to one way variance analysis after appropriate arc-sine transformation and significant differences among treatment means were based on estimates of least significant differences (LSD) at 5\% level of probability.

\section{Results}

Table 1 reveals that the insecticide treatments significantly $(\mathrm{p}<0.01)$ suppressed stalk damage caused by stemborers as the proportion of stalk tunneled were significantly $(\mathrm{p}<0.01)$ higher in the control plots. Mean separation indicates that the proportion of stalks tunneled in plots treated with the neem based treatments were comparable and each significantly $(\mathrm{p}<0.001)$ more effective than carbaryl dust. Similarly, tunnel length was significantly higher in the untreated plants. NKP+Fine sand however proved to be the most effective treatment for checking stalk tunneling. Table 1 also shows that percentage of peduncles tunneled were significantly $(\mathrm{p}<0.01)$ higher in the untreated plants. Mean separation also revealed that, the neem based treatments were significantly $(\mathrm{p}<0.01)$ more effective than carbaryl dust in this respect. Peducle tunnel length was also significantly $(\mathrm{p}<0.01)$ lower in treated with $\mathrm{NKP}+$ Fine sand being the most suppressive of the damage. Results for stalk and peduncle tunneling in year 2 presented in Table 2 also follow a somewhat similar trend with that of year 1 . Table 3 shows that the insecticide treatments resulted in significantly $(p<0.01)$ higher grain yield than the control. However, aside NKP+Fine sand, which was significantly the most effective, the other neem based treatments were statistically comparable with carbaryl dust across the years. 
Table 1. Effect of treatments on stalk damage caused by stemborers, year 1

\begin{tabular}{ccccc}
\hline Treatment & $\begin{array}{c}\text { Stalks tunneled } \\
\text { at harvest (\%) }\end{array}$ & $\begin{array}{c}\text { Stalk tunneling } \\
\text { length (\%) }\end{array}$ & $\begin{array}{c}\text { Peduncles } \\
\text { tunneled at } \\
\text { harvest (\%) }\end{array}$ & $\begin{array}{c}\text { Peduncle tunneling } \\
\text { length (\%) }\end{array}$ \\
\hline Control & 34.38 & 21.21 & 37.00 & 33.81 \\
Carbaryl dust & $(35.93)$ & $(27.40)$ & $(37.50)$ & $(35.63)$ \\
& 9.37 & 10.12 & 13.50 & 12.04 \\
NKP & $(17.73)$ & $(18.50)$ & $(21.55)$ & $(20.33)$ \\
& 6.25 & 7.98 & 8.00 & 9.68 \\
NKP + Fine & $(14.40)$ & $(16.37)$ & $(16.35)$ & $(18.15)$ \\
sand & 4.38 & 4.71 & 9.00 & 11.07 \\
NKP + Kaolin & $(11.95)$ & $(12.50)$ & $(17.40)$ & $(19.43)$ \\
dust & 5.61 & 6.09 & 9.50 & 10.79 \\
NKP + Sawdust & $(13.65)$ & $(14.17)$ & $(17.88)$ & $(19.18)$ \\
& 6.25 & 7.92 & 10.00 & 11.43 \\
Mean & $(14.40)$ & $(16.35)$ & $(18.38)$ & $(19.75)$ \\
SED & 18.01 & 17.55 & 21.51 & 22.08 \\
LSD & 1.32 & 1.31 & 1.04 & 0.65 \\
& 2.81 & 2.79 & 2.21 & 1.39 \\
& $* *$ & $* *$ & $* *$ & $*$ \\
\hline
\end{tabular}

1Mean of 4 replications; Figures in parentheses are arc-sine values to which mean, SED and LSD are applicable; ${ }^{* *}$ Significant at $1 \%$ level of probability $(\mathrm{p}<0.01)$

Table 2. Effect of treatments on stalk damage caused by stemborers, year 2

\begin{tabular}{ccccc}
\hline Treatment & $\begin{array}{c}\text { Stalks tunneled } \\
\text { at harvest (\%) }\end{array}$ & $\begin{array}{c}\text { Stalk tunneling } \\
\text { length (\%) }\end{array}$ & $\begin{array}{c}\text { Peduncles } \\
\text { tunneled at } \\
\text { harvest (\%) }\end{array}$ & $\begin{array}{c}\text { 1 } \\
\text { Peduncle } \\
\text { tunneling length } \\
\text { (\%) }^{\mathbf{1}}\end{array}$ \\
\hline Control & 30.63 & 18.53 & 33.50 & 24.93 \\
Carbaryl dust & $(33.60)$ & $(25.00)$ & $(35.40)$ & $(29.95)$ \\
& 10.63 & 9.01 & 10.00 & 11.99 \\
NKP & $(18.93)$ & $(17.53)$ & $(18.38)$ & $(20.23)$ \\
& 5.00 & 7.41 & 7.00 & 9.28 \\
NKP + Fine sand & $(12.70)$ & $(15.78)$ & $(15.30)$ & $(17.75)$ \\
& 5.00 & 4.39 & 7.00 & 9.63 \\
NKP + Kaolin dust & $(12.70)$ & $(12.10)$ & $(15.30)$ & $(18.07)$ \\
& 5.00 & 7.78 & 8.00 & 10.25 \\
NKP + Sawdust & $(12.70)$ & $(13.85)$ & $(16.35)$ & $(18.70)$ \\
& 6.25 & 7.28 & 9.00 & 10.27 \\
Mean & $(14.40)$ & $(15.63)$ & $(17.40)$ & $(18.70)$ \\
SED & 17.54 & 16.73 & 19.66 & 20.56 \\
LSD & 1.53 & 0.77 & 1.33 & 0.65 \\
& 3.26 & 1.64 & 2.84 & 1.40 \\
$* *$ & $* *$ & $* *$ & $*$ \\
\hline
\end{tabular}

1Mean of 4 replications; Figures in parentheses are arc-sine values to which mean, SED and LSD are applicable; ${ }^{* *}$ Significant at $1 \%$ level of probability $(\mathrm{p}<0.01)$ 
Table 3. Effect of treatments on grain yield

\begin{tabular}{ccccc}
\hline & \multicolumn{2}{c}{ Grain yield (kg/plot) } & \multicolumn{2}{c}{ Grain yield over control (\%) } \\
\cline { 2 - 5 } Treatment & Year 1 & Year 2 & Year 1 & Year 2 \\
\hline Control & 3.15 & 3.40 & - & - \\
Carbaryl dust & 4.50 & 4.79 & 42.86 & 40.88 \\
NKP & 4.86 & 5.31 & 54.29 & 56.18 \\
NKP + Fine sand & 5.35 & 5.57 & 69.84 & 63.82 \\
NKP + Kaolin dust & 4.95 & 5.40 & 57.14 & 58.82 \\
NKP + Sawdust & 4.86 & 5.28 & 54.29 & 55.29 \\
Mean & 4.61 & 4.96 & & \\
SED & 0.17 & 0.23 & & \\
LSD & 0.49 & 0.67 & & \\
& $* *$ & $* *$ & & \\
\hline
\end{tabular}

${ }^{1}$ Mean of 4 replications; Figures in parentheses are arc-sine values to which mean, SED and LSD are applicable; ${ }^{* *}$ Significant at $1 \%$ level of probability $(\mathrm{p}<0.01)$.

\section{Discussion}

The significant suppression of stalk and peduncle tunneling by the neem based treatments suggests that neem has antifeedant and repellent characters as reported by (Aldhous 1992; Satti et al., 2013; Okrikata et al., 2016). The comparable and sometimes superior efficacy of the neem based treatments when compared with carbaryl dust in checking stemborer damage agrees with the findings of (Adane and Asmare, 2006), who reported that, neem powder provided better control than carbaryl when used to control stemborers on sorghum.

The comparatively better efficacy of NKP+Fine sand could likely be due to the hardness and density of the fine sand component. These factors have been reported to be important in the choice of carriers used in formulating dry pesticides (Hassall, 1990). The comparatively higher hardness of fine sand vis-à-vis those of the other carriers used might have enhanced its (NKP+Fine sand) efficacy by making it (the formulation) more abrasive to the stemborer larvae leading to dehydration and death. The higher density of fine sand relative to the other carriers used will complement the effect of rain which helps to push the NKP from the tunnel where it was placed down the stalk to where the stemborer penetrated the plant, hence having it effect on the stemborer at that point. This phenomenon is very important against stemborer species that do not directly bore into the stalk through the funnel but, leave the funnel to the stembase and bore in through the stembase into the stalk to cause deadheart or tunneling as characterized by Sesamia spp.

Peduncle damage occurs during the advanced stage of the crop. Since application of treatments into the funnel of sorghum stops at the booting stage, it is obvious that the ability of the neem based treatments to suppress peduncle damage could be due to some level of persistence and systemic action (van den Berg and van Rensburg, 1991; Okrikata and Anaso, 2008).

(Adane and Asmare, 2006; Chunshan et al., 2011) reported the very high efficacy of neem products in controlling stemborer infestations. Their findings also reveal that, neem products check stemborer menace to the same magnitude, and sometimes more than synthetic insecticides. A related information has been reported by (Anaso, 1999), who reported the efficacy of different dosages of aqueous neem seed extract than carbaryl in checking leaf feeding damage by flea beetles on okro. 
All the insecticide treatments gave higher grain yield than the control with NKP+Fine sand being the most effective. This observation is not unconnected with the efficacy of the neem based treatments in checking stalk and peduncle damage as discussed above and also buttressed the finding of (Asawalam 2007; Ogah et al., 2011; Wahedi et al., 2016) who reported the grain yield of neem treated plots being comparable to that obtained with furadan (a systemic insecticide against stemborers) and 1.5 times higher than control.

\section{Conclusion}

Stemborers were prevalent and significantly reduce yield of sorghum in the semi-arid zone of Nigeria and the neem dust formulations were more effective than carbaryl dust in protecting the crop. NKP+Fine sand was generally more effective than the other neem based treatments and the ability of the neem based treatments to check peduncle damage suggests some sort of persistence and systemic action. That the neem based formulations and particularly, NKP+Fine sand were more effective than carbaryl in suppressing borers damage with a resultant increase in yield, coupled with ease of preparation, use, safety in handling and environmental friendliness of the neem dust formulations, indicates that the neem based treatments could be useful components of the integrated pest management strategy for sorghum stemborers.

\section{Acknowledgements}

We are grateful to the Head of Department of Crop Protection for permission to use the facilities in the departmental research farm and also the management and staff of Borno State Agricultural Development Programme for providing seeds for the research. We acknowledge the technical assistance of Mr. Apagu Kambyari and the constructive criticism and contributions of Late Professor A. B. Anaso during the field trials.

\section{References}

Adegbola, AJ, Awagu, EF, Kamaldeen, OS, Kashetu, RQ. (2013). Sorghum: Most underutilized grain in the semi-arid Africa. Scholarly J. Agric. Sci., 3(4): 147-153.

Adane, T, Asmare, D. (2006). Evaluation of neem (Azadirachta indica) derivatives for management of Sorghum Stem borers Busseola fusca (Fuller) and Chilo partellus (Swinhoe). Eth. J. Sci. \& Technol., 3(2): 69-80.

Ahmed, S, Grainge, M. (1986). Potential of neem tree (Azadirachta indica) for pest control and rural development. Econ. Bot., 40:201-209.

Ajala, SO, Nour, AM, Ampong-Nyarko, K, Odindo, MO. (2010). Evaluation of maize genotypes as a component of integrated stem borer (Chilo partellus Swinhoe) management in coastal region of Kenya. Afri. J. Agric. Res., 5(8):758 - 763.

Aldhous, P. (1992). Neem chemicals: the pieces fall into place. Science, 258:893.

Anaso, CE. (1999). Evaluation of neem seed extracts for control of major insect pests of okra (Abelmoschus esculentus ) in Nigeria Sudan savanna. Ph.D. Thesis, University of Maiduguri Nigeria. 
Asawalam, EF, Emosairue, SO, Ekeleme, F, Wokocha, RC. (2007). Insecticidal effects of powdered parts of eight Nigerian plant species against Maize weevil, Sitophilus zeamais Motschulsky (Coleoptera: Curculionidae). Electronic J. Environ. Agric. Food Chem., 6(11):2226-2533.

Chunshan, G, Wei, G, Xue, F, Jianzhou, Z, Guihua, L. (2011), Sorghum insect problems and management. J. Integrative Plant Biol., 53(3):178-192.

Hassall, KA. (1990). The Biochemistry and Uses of Pesticides, 2nd ed. Macmillan, London. pp 536.

Kfir, R, Overholt, WA, Khan, ZR. Polaszek, A. (2002). Biology and management of economically important lepidopteran cereal stemborers in Africa. Annu. Rev. Entomol., 47:701-731.

Malgwi, AM. Adamu, H. (2013). Effects of foliar applied carbofuran on damage and yield of some sorghum varieties/cultivars caused by stemborer, Busseola fusca (Fuller) in Biu, Borno State. ARPN J. Sci. \& Tech., 3(9): 963 - 971.

Mathieu, B, Ratnadass, A, Abba Gary, A, Beyo, J, Moyal, P. (2006). Losses caused by stemborer to transplanted sorghum crops in northern Cameroon. Int. sorghum millet newslett., 47:75-77.

Monitoring African Food and Agricultural Policies (MAFAP) (2013). Analysis of incentives and disincentives for Sorghum in Nigeria.http://www.fao.org/fileadmin/templates/mafap/documents/technical_notes/NIG ERIA_Technical_Note_SORGHUN_EN_Jul2013.pdf

Ogah, E0, Omoleye, AA, Nwilene, FE. Nwogbaga, AC. (2011). Effect of neem seed kernel extracts in the management of Rice Stem borers in the field in Nigeria. Nig. J. Biotech., 23(1): $13-21$.

Okrikata, E, Anaso, CE. (2008). Influence of some inert diluents of neem kernel powder on protection of Sorghum against Pink Stalk Borer (Sesamia calamistis, Homps) in Nigerian Sudan Savanna. J. Plant Protect. Res., 48(2):161-168.

Okrikata, E, Mai Bukar, S, Ali, B. (2016). Economic viability of chilli pepper and neem seed kernel powdered formulations vis-à-vis sevin dust (85\%) in the management of lepidopterous stemborers on sorghum in North eastern Nigeria. J. Biol, Agric. \& Healthcare, 6(21):99-103.

Okweche, SI, Ogunwolu, EO. Adeyemo, MO. (2013). Parameters, interrelationships with yield and use of carbofuran to control stem borers in maize at Makurdi, in the Nigerian Southern Guinea Savanna. Greener J. Agric. Sci., 3(10): 702 - 708.

Oswald, A. (2005). Striga control technologies and their dissemination. Crop Protection. 24:333-342.

Satti, AA, Elamin, MM, Fatuwi, A. (2013). Insecticidal effects of neem (A. Juss) oils obtained from neem berries at different periods. The Experiment. 6(2):330-337. 
Seshu Reddy, KV. (1988). Assessment of on-farm field losses in sorghum due to insect pests. Insect Sci. Applic. 9(6):679-685.

van den Berg, J. (2009). Case Study: Vertiver grass as component of integrated pest management systems. http://www.vertiver.org/ETH_WORKSHOP_09/ETH_A3a.pdf

van den Berg, J, van Rensburg, J.B.J. (1991). Infestation and injury levels of stem borers in relation to yield potential of grain sorghum. South Afr. J. Plant \& Soil. 8(3):127-131.

Wahedi, JA, David, DL, Danba, EP, Yisa, S, Zakariya, R. (2016). Yield performance of Maize treated with neem seed extracts against stem borers. Am. J. Expt. Agric. 12(6): 1-8.

How to cite this article: Emmanuel Okrikata, Chinwe Edith Anaso. Evaluation of Neem Dust Formulations for the Control of Sorghum Stemborers in the Semi-Arid Zone of Nigeria. International Journal of Advanced Biological and Biomedical Research, 2019, 7(4), 298-305. Link: http://www.ijabbr.com/article 35357.html 